\title{
Larvicide and insecticide activity of the essential oil of Ocimum sanctum var. cubensis in the control of Musca domestica (Linnaeus, 1758), under laboratory conditions
}

\author{
Actividad larvicida e insecticida del aceite esencial de Ocimum sanctum var. cubensis en \\ EL CONTROL DE Musca domestica (Linnaeus, 1758), en condiciones de laboratorio
}

\section{Atividade larvicida e inseticida do óleo essencial de Ocimum sanctum var. cubensis no CONTROLE DE Musca domestica (Linnaeus, 1758), em condições de laboratório}

Received: October 6, 2020

Accepted: November 11, 2020
Abstract

Essential oils have been considered as an important alternative facing synthetic pesticides. The control of the species Musca domestica is very important for public health due to their role as vector associated with Vibrio cholerae, Salmonella and Shigella, among other pathogens. The objective of this work was to evaluate the larvicidal and insecticidal efficacy of the essential oil of Ocimum sanctum var. cubensis, in the control of Musca domestica and its effect on the post-embryonic development of this species. The essential oil was applied topically in six concentrations to newly hatched larvae $(1 \mu \mathrm{L} /$ larva). Mortality, interval length of each development period, as well as the weight of mature larvae were analyzed. An insecticidal bioassay was also carried out in adult flies. The essential oil of $O$. sanctum caused a slight reduction in the larval and pupal period for some of the concentrations evaluated. The time of development of the newly hatched larvae until the

\section{Resumen}

Los aceites esenciales han sido considerados una alternativa importante frente a los pesticidas sintéticos. El control de la especie Musca domestica es muy importante para la salud pública debido a su papel como vector asociado con Vibrio cholerae, Salmonella y Shigella, entre otros patógenos. El objetivo de este trabajo fue evaluar la eficacia larvicidas e insecticida del aceite esencial de Ocimum sanctum var. cubensis, en el control de Musca domestica y sus efectos en el desarrollo post-embrionario de esta especie. El aceite esencial fue aplicado tópicamente en seis concentraciones en neolarvas ( $1 \mu \mathrm{L} /$ larva). Fueron analizados la mortalidad, el intervalo de cada periodo de desarrollo y el peso de las larvas maduras tratadas. También se llevó a cabo un ensayo insecticida en moscas adultas. El aceite esencial de O. sanctum causó una ligera reducción en los periodos larval y pupal para algunas de las concentraciones evaluadas. El tiempo de

\footnotetext{
${ }^{9}$ Laboratório de Entomologia Médica e Forense, Instituto Oswaldo Cruz, Fundação Oswaldo Cruz (IOC/FIOCRUZ), Rio de Janeiro, Brazil.

${ }^{10}$ Departamento de Farmacia, Facultad de Ciencias Naturales y Exactas, Universidad de Oriente, Santiago de Cuba, Cuba.

${ }^{11}$ Projeto Capes (Ministério da Educação do Brasil) - MES (Ministerio de Educación Superior de Cuba).

${ }^{12}$ Mestrado Profissional em Ciências Ambientais, Universidade Severino Sombra - USS, Rio de Janeiro, RJ, Brazil.

${ }^{13}$ Núcleo de Ciências Fisiológicas, Universidade Federal do Amapá, Campus Binacional do Oiapoque, Amapá, Brasil.

${ }^{14}$ Laboratório de Genética y Genômica Aplicada, Escuela de Ciencias del Mar, Pontificia Universidad Católica de Valparaíso, Chile.
} 


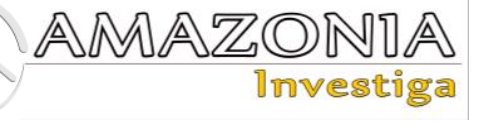

adult period was shortened in all the concentrations analyzed. The larvae of the control group were the heaviest. The effectiveness of the product in the control of the larvae of the flies of the species $M$. domestica was greater than $50 \%$, except for those larvae treated with $80.25 \mathrm{mg} / \mathrm{mL}$ of the essential oil. The lethal concentration for adult insects LC50 was estimated at $9.41 \mu \mathrm{g}$. Results demonstrated that the essential oil of $O$. sanctum has effect in all stages of the life cycle of M. domestica, extolling its potential as an effective insecticide against this species.

Keywords: Ocimum tenuiflorum L, basil, control of M. domestica, insecticide, post-embryonic development. desarrollo de neolarva hasta adulto fue más corto en todas las concentraciones analizadas. Las larvas del grupo control fueron más pesadas. La efectividad del producto en el control de larvas de la especie M. domestica fue mayor que el $50 \%$, excepto para las larvas tratadas con dosis del aceite esencial de $80.25 \mathrm{mg} / \mathrm{mL}$. La concentración letal para insectos adultos LC50 fue estimada en $9.41 \mu \mathrm{g}$. Los resultados demostraron que el aceite esencial de O. sanctum tiene efecto en todos los estadios del ciclo de vida de la especie $M$. domestica, mostrando su potencial como un insecticida efectivo contra esta especie de moscas.

Palabras claves: Ocimum tenuiflorum L, albahaca, control de M. domestica, insecticida, desarrollo post-embrionario.

\section{Resumo}

Os óleos essenciais têm sido considerados uma alternativa importante aos pesticidas sintéticos. O controle da espécie Musca domestica é de grande importância para a saúde pública devido ao seu papel como vetor associado ao Vibrio cholerae, Salmonella e Shigella, entre outros patógenos. O

objetivo do trabalho foi avaliar a eficácia larvicida e inseticida do óleo essencial de Ocimum sanctum var. cubensis, no controle de Musca domestica e seus efeitos no desenvolvimento pós-embrionário desta espécie. O óleo essencial foi aplicado topicamente em seis concentrações em neolarvas ( $1 \mu \mathrm{L} /$ larva). Foram analisados a mortalidade, o intervalo de cada período de desenvolvimento e o peso das larvas maduras tratadas. Um teste inseticida também foi realizado em moscas adultas. O óleo essencial de $O$. sanctum causou ligeira redução nos períodos larval e pupal para algumas das concentrações avaliadas. O tempo de desenvolvimento do neolarva até adulto foi menor em todas as concentrações analisadas. As larvas do grupo controle foram mais pesadas. A eficácia do produto no controle das larvas da espécie $M$. domestica foi superior a 50\%, exceto para a larvas tratadas com óleo essencial em dose de 80,25 mg / mL. A concentração letal para insetos adultos $\mathrm{LC}_{50}$ foi estimada em $9,41 \mu \mathrm{g}$. Os resultados mostraram que o óleo essencial de $O$. sanctum atua em todas as fases do ciclo de vida da espécie $M$. domestica, mostrando seu potencial como inseticida eficaz contra esta espécie de moscas.

Palavras-chave: Ocimum tenuiflorum L, manjericão, controle de $M$. domestica, inseticida, desenvolvimento pós-embrionário.

\section{Introduction}

Synanthropic flies, of the non-chopper type (Calliphoridae, Muscidae and Sarcophagidae families) live in association with man and are capable of reproducing in scavengers and decomposing organic matter. Due to their habits, these flies can transport various pathogenic microorganisms, such as viruses, bacteria and protozoa, a fact that highlights the importance of their control for public health. It is known that the spread of these pathogens occurs through the external region of their body (legs, wings and thorax), by regurgitation of their food on surfaces and also by means of their contaminated feces (Greenberg, 1973; Lindeberg et. al 2018).

Musca domestica (Linnaeus, 1758) (Diptera: Muscidae) is among the most important species due to its synanthropic behavior and worldwide distribution. This fly is considered to play an important role in infectious diseases transmitted to foods such as Vibrio cholera, Escherichia coli, Salmonella and Shigella. They can also transport cysts and oocysts of protozoa, helminth eggs and, in addition, they are being responsible for the production of myiasis inhumans and animals (Themanma et. al, 2013).

Few studies have shown the positive impact of fly control measures on the incidence of diarrhea in developing countries (Chavasse et. al, 1999; Collinet-Adler et. al, 2015; Hadi et. al, 2018). In Japan, mechanical transmission by flies of the H5N1 virus (subtype of influenza A virus), which causes bird flu, was suggested (Sawabe 
et.al, 2006; Sawabe et.al, 2011). Graczyket et. al (2001) showed the importance of non-chopper flies in the transmission of human infectious diseases, mainly for children in sub-Saharan Africa and the relationship of these insects with the transmission of nosocomial infections, enteropathogens and in the epidemiology of human intestinal helminthosis (Adenusi \& Adewoga, 2013). The flies are also responsible for causing or producing myiasis, an infestation by larvae of flies in human or animal tissues that usually ends in tissue necrosis when not treated or even death when is not reverted in early stages (Sukontason et. al, 2005).

Musca domestica has adaptive mechanisms that have facilitated the appearance of resistance to synthetic chemical insecticides (Shah, Shad \& Abbas, 2016; Khan, 2017).This species has a short life cycle, presenting easy adaptation to the environment. This confers resistance to insecticides when applied in the medium, such as DDT, Malathion and others commonly used in Europe, Asia and America (Shono \& Scott, 2003; Srinivasan, Jambulingam \& Gunasekaran, 2008).

It is a fact that resistance to insecticides is increasing worldwide and is one of the most complex pest control problems at present. There have been documented 447 species of insects and mites that developed resistance to one or more chemical and organic groups (Georghiou, 1994; David et. al, 2007). Also the effects of pesticides on health are observed in risk groups in developing countries (WHO, 1990). Deaths and chronic diseases are reported worldwide due to pesticide poisoning in a number of around 1 million per year (Environews Forum, 1999). High-risk pesticide groups include production workers, formulators, sprayers, mixers, loaders, and agricultural workers, that's why it is important to find natural products capable of replacing them (Aktar, Sengupta \& Chowdhury, 2009).

The aromatic plants and its essential oils have been extensively used for a lot of activities and applications for human use, such as flavors and fragrances, condiments or spices, folk medicines (Bakkali et al, 2008) and to repel insects or to protect the stored products (Miresmailli \& Isman, 2014). Among these plants, several species of the genus Ocimum (known as basil), belonging to the Lamiacea family, have an economic importance in obtaining essential oils, having use in popular medicine on all continents (Pattanayak, Behera, Das \& Panda, 2010; Rashid, Banerje \& Jyoti, 2013).
The long history of use of essential oils has facilitated product approval mechanisms in countries such as the USA, which has contributed to their considered well-being as important alternative to synthetic pesticides. On the other hand, essential oils are environmentally friendly bioorganic compounds which are easily biodegradableand have little or no toxicity against fish, birds and mammals (Isman, 1997; Stroh, Wan, Isman \& Moul, 1998).

Among the essential oils studied for their possible insecticidal action, Ocimum sanctum is one of them, confirming that both, the essential oil and its major constituent, eugenol, are very toxic against mosquito species Aedes aegypti Linnaeus, Anopheles stephensi Liston, and Culex quinquefasciatus (Say) (Peter, Van den Bossche, Penzhorn \& Sharp, 2005; Tawatsin et al, 2006).

The repellent activity of eugenol, the main component of the essential oil of O. sanctum, has also been proven against four species of coleoptera: Sitophilus granarius, Sitophilus zeamais, Tribolium castaneum and Prostephanustruncates, with promisory results (Obeng-Ofori \& Reichmuth, 1997).

Only few studies report this activity against other species of flies (Chil-Núñez et. al, 2018) for this Lamiacea, and there are not any findings referred to Musca domestica species, which is an insects with a great medical-sanitary importance.

This work describes the larvicidal and insecticidal efficacy of the essential oil of Ocimum sanctum var. cubensis, in the control of Musca domestica and its effect on the postembryonic development of this species.

\section{Theoretical framework}

\section{Therapeutic uses of Ocimum sanctum $L$.}

Several medicinal properties have been attributed to Ocimum sanctum L. (syn. Ocimum tenuiflorum L). Different parts of Basil plant are known to possess therapeutic abilities and have been used by traditional medical specialists in treatment of fever, bronchitis, arthritis, convulsions, also as expectorant, analgesic, anticancer, antidiabetic, antiasthmatic, hypotensive, antiemetic, diaphoretic, antifertility, hepatoprotective, hypolipidmic, and antistress agents (Prakash \& Gupta, 2005).

Botanic Insecticides

Some plants, throughout evolution developed their own chemical defense against herbivorous 


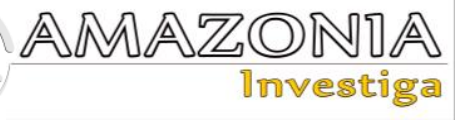

insects, synthesizing metabolities with insecticide properties; to wit, with toxic activity against insects or that cause their death by others action ways or their repellency. Botanic insecticides are products derived of plants or parts of plants, clouding be the own vegetal material, usually ground until pulverize, or their products derived by watery extraction or as organic solvents or distillation results (Wiegmann et. al, 2004).

\section{Methods}

Bioassay

Houseflies: A colony of M. domestica was established using insects trapped on the campus of Fundação Oswaldo Cruz, Rio de Janeiro. Flies were kept in cages at Laboratório de Entomologia Médica e Forense, located at the same institution, and they were feed ad libitum with water and sugar. Protein, in the form of bovine meat mixed with wheaten husk $(6: 4 \mathrm{w} / \mathrm{w})$, was given to stimulate oviposition and to feed the larvae. The experiments were maintained in acclimatized chambers set at $27 \pm 1{ }^{\circ} \mathrm{C}, 60 \pm 10 \%$ $\mathrm{RH}$ and 12:12 (L: D) light cycle and the observations were recorded daily. All bioassays were performed using second and third laboratory generation (F2 and F3).

Larvicidal bioassay: For testing the effects of $\mathrm{O}$. sanctum essential oil, six concentrations were prepared using dimethylsulfoxide (DMSO) as solvent $(4.13,8.25,20.63,41.25,61.87$ and 80 . $25 \mathrm{mg} / \mathrm{mL})$. Two controls groups were used during experiments; one of them using only DMSO (solvent control) and no substances were added for the other one (pure control).

The essential oil was applied topically to newly hatched larvae in a group of 50 insects $(1 \mu \mathrm{L} /$ larva), using an automatic pipettes. After treatment, the larvae were transferred to a recipient (capacity of $50 \mathrm{~mL}$ ) containing bovine putrefied meat $(50 \mathrm{~g})$, with a proportion of $1 \mathrm{~g}$ of meat for each larva, to guarantee enough food for maximum development. These recipients $(50 \mathrm{~mL})$ were placed in larger ones $(500 \mathrm{~mL})$ containing vermiculite as a substratum for pupation and were covered with a nylon fabric held down with rubber band. After reaching maturity, the larvae spontaneously abandoned the diet and were individually weighed and transferred to glass tubes until imago emergence. Bioassays were performed in quadruplicate.

Mortality and duration of each developmental period (larval, pupal and newly-hatched larvae to adult) were analyzed, as well as the weight of mature larvae. The efficacy of the essential oil on larvae was calculated according to Kumar et al. (2013) using the following formula: larval efficacy $=[$ (number of live larvae in pure control group - number of live larvae in treatment group) / number of live larvae in pure control group] X 100.

Insecticidal bioassay: A piece of filter paper $(2 \times 2$ $\mathrm{cm})$, impregnated with $30 \mu \mathrm{L}$ of the essential oil of $\mathrm{O}$. sanctum was positioned at the bottom of a Falcon tube $(50 \mathrm{~mL})$ for each one of the six tested concentrations in larvae. At each tube, 30 houseflies' adults with 15-20 days-old were placed and the tubes were covered with a nylon fabric held down with rubber band. Observations for adult knockdown or death were made each ten minutes after application up to 120 minutes. The experiment was performed by quintuplicate with the same control groups (with DMSO and without addition of any substance). The efficacy of the essential oil on adults was calculated using the formula proposed by Kumar et al. (2013), but replacing the number of larvae by the number of adults.

\section{Statistical analysis}

The results were analyzed by ANOVA $(p \leq 0.05)$ and the mean values were compared by the Tukey-Kramer test at the 0.05 significance level. Mortality was corrected using the Abbot formula (Abbott, 1925). Probit analysis of concentrationmortality data was used to estimate the LC50 values and their associated $95 \%$ confidence limits for each treatment. Pearson's test was accomplished to determine a cause-effect relation. All the statistical analysis was made helped by the SPSS 18.0.0 /2009 for Windows.

\section{Results}

\section{Activity against housefly larvae}

The essential oil of $O$. sanctum caused a slightly reduction at larval period in all concentrations tested, excepted at $80.25 \mathrm{mg} / \mathrm{mL}$. These results were also observed at pupal period, however, only $41.25 \mathrm{mg} / \mathrm{mL}$ and $61.87 \mathrm{mg} / \mathrm{mL}$ concentrations caused a statistically significant alteration of the development time, when compared to control group. The newly-hatched larvae to adult period were shortened by all concentrations tested, when comparing to control group (table 1), but $61.87 \mathrm{mg} / \mathrm{mL}$ was once again one of the most significant concentrations. 
Table 1.

Time, in days, of postembryonic development period of Musca domestica (Diptera: Muscidae) topically treated with different concentrations of essential oil extracted from Ocimum sanctum var. cubensis.

\begin{tabular}{llll}
\hline $\begin{array}{l}\text { Essential oil } \\
\text { Ocimum sanctum } \\
(\mathrm{mg} / \mathrm{mL})\end{array}$ & Larval stage & Pupal stage & $\begin{array}{l}\text { Newly-hatched larvae } \\
\text { to adults }\end{array}$ \\
\cline { 2 - 4 } & $\mathrm{X} \pm \mathrm{DP}$ & $\mathrm{X} \pm \mathrm{DP}$ & $\mathrm{X} \pm \mathrm{DP}$ \\
Control & $5.36 \pm 0.48^{\mathrm{a}}$ & $4.13 \pm 0.33^{\mathrm{b}}$ & $9.48 \pm 0.50^{\mathrm{a}}$ \\
DMSO & $5.35 \pm 0.48^{\mathrm{a}}$ & $4.19 \pm 0.39^{\mathrm{b}}$ & $9.58 \pm 0.49^{\mathrm{a}}$ \\
4.13 & $5.11 \pm 0.31^{\mathrm{b}}$ & $4.18 \pm 0.32^{\mathrm{b}}$ & $9.23 \pm 0.43^{\mathrm{b}}$ \\
8.25 & $5.20 \pm 0.40^{\mathrm{a}}$ & $4.21 \pm 0.41^{\mathrm{b}}$ & $9.31 \pm 0.47^{\mathrm{b}}$ \\
25.20 & $5.27 \pm 0.44^{\mathrm{a}}$ & $4.11 \pm 0.31^{\mathrm{b}}$ & $9.36 \pm 0.48^{\mathrm{a}}$ \\
41.25 & $5.00 \pm 0.01^{\mathrm{c}}$ & $4.38 \pm 0.49^{\mathrm{a}}$ & $9.42 \pm 0.49^{\mathrm{a}}$ \\
61.87 & $5.16 \pm 0.37^{\mathrm{b}}$ & $4.03 \pm 0.17^{\mathrm{c}}$ & $9.21 \pm 0.41^{\mathrm{b}}$ \\
80.25 & $5.39 \pm 0.49^{\mathrm{a}}$ & $4.11 \pm 0.39^{\mathrm{b}}$ & $9.50 \pm 0.50^{\mathrm{a}}$ \\
\hline
\end{tabular}

*Values within a column followed by the same letter are not significantly different at the $5 \%$ level according to Tukey's Multiple Comparison Test.

The larvae from the control group were the heaviest $(24.10 \pm 1.26 \mathrm{mg})$ with statistical difference from control with DMSO and for all tested concentrations, except to $50 \%$. As seen in table 2, at higher concentrations (61.87 and 80.25 $\mathrm{mg} / \mathrm{mL})$ it was found the lowest larvae weight gain $(20.37 \pm 2.38 \mathrm{mg}$ and $21.14 \pm 1.88 \mathrm{mg}$, respectively).

Table 2.

Larval weight (mg) of Musca domestica (Diptera: Muscidae) topically treated with different concentrations of essential oil extracted from Ocimum sanctum var. cubensis.

\begin{tabular}{lll}
\hline essential oil Ocimum sanctum $(\mathrm{mg} / \mathrm{mL})$ & $\begin{array}{c}\text { Larval weight } \\
\text { Mean }\end{array}$ & $\begin{array}{l}(\mathrm{mg}) \\
\text { SD }\end{array}$ \\
\hline Control & $24.10^{\mathrm{a}}$ & 1.26 \\
DMSO & $22.80^{\mathrm{b}}$ & 1.84 \\
4.13 & $22.85^{\mathrm{b}}$ & 2.24 \\
8.25 & $22.92^{\mathrm{b}}$ & 2.6 \\
25.20 & $22.87^{\mathrm{b}}$ & 2.83 \\
41.25 & $23.47^{\mathrm{ab}}$ & 1.67 \\
61.87 & $20.37^{\mathrm{c}}$ & 2.38 \\
80.25 & $21.14^{\mathrm{c}}$ & 1.88 \\
\hline
\end{tabular}

*Values within a column followed by the same letter are not significantly different at the 5\% level according to Tukey's Multiple Comparison Test.

The effectiveness of the product in the control of $M$. domestica larvae was greater than $50 \%$ except for the larvae treated with $80.25 \mathrm{mg} / \mathrm{mL}$ of the oil (Figure 1). No statistically significant differences were observed between the total killed larvae for the rest of experimental groups ( $p>0.05$ ). Moreover, the efficacy of the essential oil on adult's emergence was greater than $60 \%$ for intermediate concentrations (20.63, 41.25 and $61.87 \mathrm{mg} / \mathrm{mL}$ ) and also greater than those obtained in the larval stage. For this stage, it was observed statistically significant differences between experimental and controls groups but not between the tested concentrations ( $p>0.05)$. 


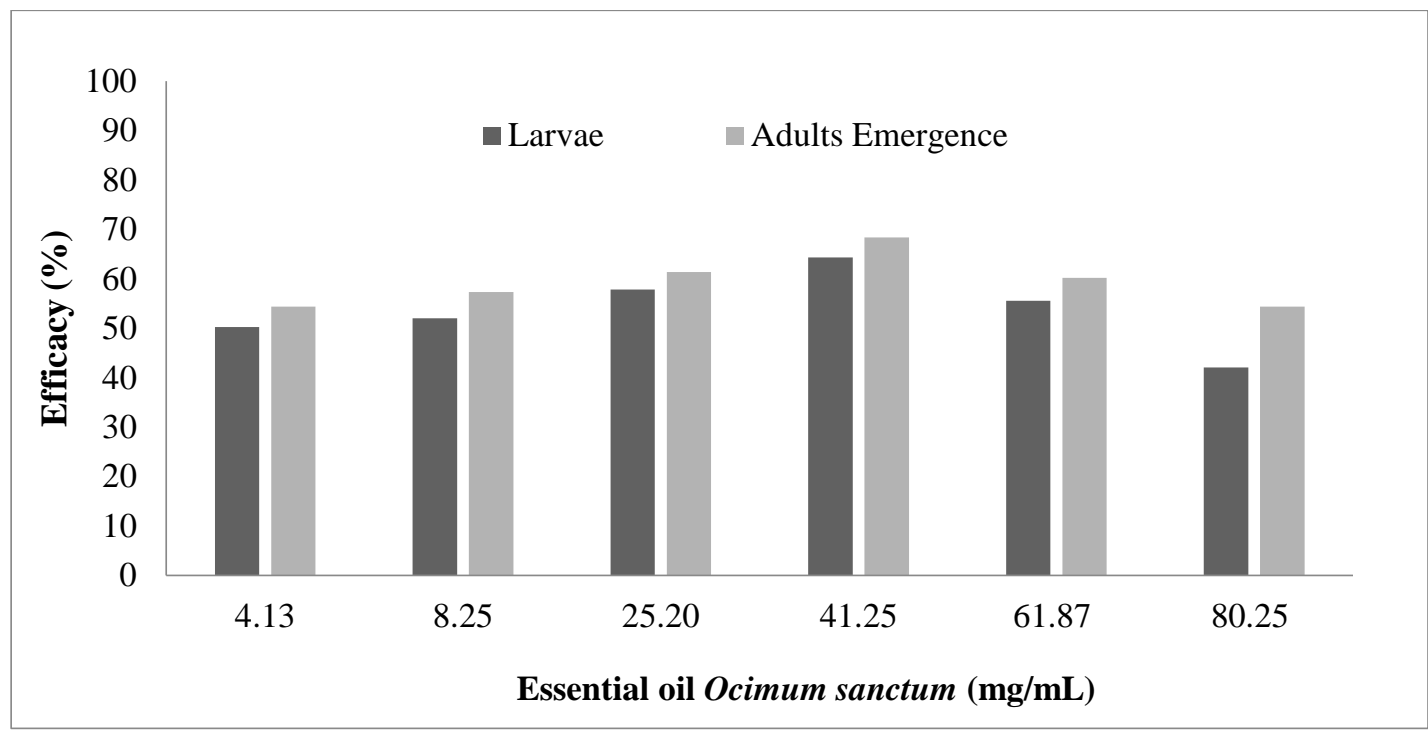

Figure 1. Larvae and adults emergency efficacy (\%) of Musca domestica (Diptera: Muscidae) topically treated with different concentrations of essential oil extracted from Ocimum sanctum var. cubensis.

Activity against housefly adults

Table 3 presents the number of houseflies dead and/or knockdown after the tests using the same six concentrations of basil essential oil. Biological activity observed shows that the mortality is also dose-dependent. The lower concentrations (4.13 and $8.25 \mathrm{mg} / \mathrm{mL})$ only provoked knockdown/paralyzation 70 minutes after application and no death at the end of the experiment (120 minutes) was observed. On the other hand, at the highest concentration (80.25 $\mathrm{mg} / \mathrm{mL}$ ) all flies died after one hour of exposition.

The lethal concentration $\mathrm{LC}_{50}$, was estimated in $10.69 \%(9.41 \mu \mathrm{g})$ and, according to Pearson's test a cause-effect relation was observed $(\mathrm{p}<0,0001)$.

Table 3.

Number of adults from Musca domestica (Diptera: Muscidae) dead and/or knockdown using different concentrations of essential oil extracted from Ocimum sanctum var. cubensis.

\begin{tabular}{|c|c|c|c|c|c|c|c|c|c|c|c|c|c|}
\hline \multirow{2}{*}{\multicolumn{2}{|c|}{$\begin{array}{l}\text { essential oilmg/mL / } \\
\text { time }\end{array}$}} & 10 & 20 & 30 & 40 & 50 & 60 & 70 & 80 & 90 & 100 & 110 & 120 \\
\hline & & $\min$ & $\min$ & $\min$ & $\min$ & $\min$ & $\min$ & $\min$ & $\min$ & $\min$ & $\min$ & $\min$ & $\min$ \\
\hline 4.13 & $\begin{array}{l}\text { knockdown } \\
\text { dead }\end{array}$ & & & & & & & 29 & 33 & 34 & 39 & 43 & 52 \\
\hline 8.25 & $\begin{array}{l}\text { knockdown } \\
\text { dead }\end{array}$ & & & & & & & 32 & 34 & 37 & 42 & 53 & 61 \\
\hline \multirow[t]{2}{*}{25.20} & knockdown & & 30 & 57 & 19 & 22 & 29 & 25 & 21 & 29 & 24 & 22 & 24 \\
\hline & dead & & & & 51 & 71 & 74 & 86 & 97 & 99 & 106 & 111 & 122 \\
\hline \multirow[t]{2}{*}{41.25} & knockdown & & 58 & 90 & 89 & 87 & 64 & 79 & 42 & 17 & & & \\
\hline & dead & & & & 11 & 29 & 52 & 65 & 101 & 133 & 150 & & \\
\hline \multirow[t]{2}{*}{61.87} & knockdown & 50 & 70 & 51 & 52 & 72 & 64 & 33 & 19 & & & & \\
\hline & dead & & & 39 & 60 & 78 & 86 & 117 & 131 & 150 & & & \\
\hline \multirow[t]{2}{*}{80.25} & knockdown & 100 & 30 & 22 & 5 & 3 & & & & & & & \\
\hline & dead & 21 & 115 & 123 & 145 & 147 & 150 & & & & & & \\
\hline \multirow[t]{2}{*}{ DMSO } & knockdown & & & & & & & & & & & & 0 \\
\hline & dead & & & & & & & & & & & & 0 \\
\hline
\end{tabular}




\section{Discussion}

Activity of essential oil against domestic fly larvae

Plant essential oils could be considered an alternative to control insect species (ViegasJunior, 2003). Most published studies evaluate the efficacy of these substances against adults of M. domestica (Bosly, 2013; Kumar, Mishra, Malik \& Satya, 2011) ignoring the influence they could have on all life cycles. That is why an integrated analysis should also be considered seeing the post embryonic development period and the adult phase.

As shown in Table 1, the essential oil of $O$. sanctum affected all developmental stages. Throughout the larval period, all concentrations evaluated caused a slight reduction in time, except $80.25 \mathrm{mg} / \mathrm{mL}$. This similarity between the pure essential oil $(80.25 \mathrm{mg} / \mathrm{mL})$ and the control group is also observed in the other developmental stages of the flies. A similar behavior was observed in our research group when the same essential oil was evaluatedagainst Chrysomya putoria (Diptera: Calliphoridae), which suggests that due to the experimental conditions (ChilNúñez et. al, 2018), the pure essential oil could evaporate and in this way remain less time in contact with the larvae.

The essential oil of basil also reduced the weight of the larvae in all tested concentrations that affect the pupa and the emergence of the adults and also cause more than $50 \%$ of the mortality. As reporter in literature, Diptera larvae usually leave the diet when the amount of available nutrients is not enough or the competition level between larvae is very high, which affects the duration of the different stages and the weight of the larvae (Chapman, 2003). However, as described in the methodology, sufficient food supplies were guaranteed in the experiment. That's why the reduction in development time and weight of the larvae, as well as the emergency efficacy, can be attributed as a result of the effect of the oil essential of basil.

The major components of Ocimum sanctum var. cubensis essential oil were: Eugenol (21.96\%), $\beta$ caryophyllene $(20.79 \%)$, Bicyclogermacrene (20.38\%), $\beta$-Selinene (7.69\%) and Linalool (7.13\%) (Chil-Núñez et. al, 2017). Eugenol, the main compound in the tested basil oil is reported as a valuable substance for controlling insects, generally for its anti-food property (Schowalter, 2006).This could be a reasonable explanation about why basil essential oil reduces the larval weight and developmental period, transforming the food supplies into a not appetizing option.

On the other hand, several monoterpenoids, such as linalool and menthol exhibited neurotoxicity activity against housefly acting as acetylcholinesterase inhibitors (Ryan\& Byrne, 1998). Linalool is the fifth most abundant component in basil essential oil with a $7.13 \%$, being able to be one of the responsible for the insecticidal activity observed. Methyl-eugenol is one of the essential oil most frequently reported as good insecticide (Vargas et.al, 2010; Leblanc et. al, 2011). Even when in some the sample collected in Cuba, this compound is not present in great quantities, it has been described as one of the main substances in other latitudes and its close chemical relationship with eugenol is more than evident.

For others basil main compounds ( $\beta$ caryriophyllene and bicyclogermacrene) few reports as insecticide has been found (Hantan\& Zaki, 1998; Edigenia et. al, 2003; Kasrati et. al, 2015). Nevertheless, in the complex mixture that means an essential oil, other minor compounds would be able to increase the activity by a synergistic action (Lambert, Skandamis, Coote \& Nychas, 2001; Bakkali, Averbeck, Averbeck \& Burt, 2004; Idaomar, 2008; Pinto et al, 2015).

\section{Activity against housefly adults}

No reports based on the insecticidal activity of the essential oil of O.sanctum on M. domestica were found in the literature. The results of the present study agree with the description of Sinthusiri and Soonwera (2013) when they studied the insecticidal effect of $O$. basilicum essential oil on this species. In both investigations, it was observed that at concentrations of $10 \%$ of the essential oil, the effect on adult flies is classified as lowe, even after 60 minutes. However, Sinthusiri and Soonwera (2013) did not experiment at higher concentrations (over 10\%), in which the oil of $O$. basilicum turned out very effective not only in the time in which the insecticidal effects appears but also in the number of affected flies, according to the results of this investigation.

It is relevant that the pure essential oil of $O$. sanctum affects the $81 \%$ of the flies $(67 \%$ knockdown and $14 \%$ dead) in the first 10 minutes (Table 4). It is important to remark that flies reported as knockdown/paralyze never against recover their vitality; getting dead the $100 \%$ just in longer periods of time. This event (fly death) occurs usually 20 minutes after the flies get in 


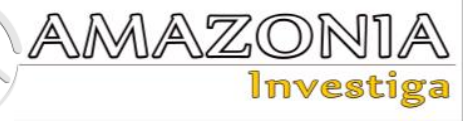

knockdown. This sequence (the knockdown effect before death) was attributed to sesquiterpenes in others studies (Viegas-Junior, 2003; Sinthusiri \& Soonwera, 2013), a kind of substances that are quite abundant in the basil essential oil.

Regarding to lethal doses, Pavela (2008) reported a $\mathrm{LC}_{50}$ for $O$. basilicum essential oil topic application in adults of M. domestica of 15 $\mu \mathrm{g} / \mathrm{fly}$. In our study, we obtain $\mathrm{aLC}_{50}$ equivalent to $9.41 \mu \mathrm{g} / \mathrm{fly}(10.69 \%)$. Quite similar to Pavela (2008), Bertoni (2013) when experimented with a Colombian basil essential oil determinate $\mathrm{LC}_{50}$ $10.4 \mathrm{mg} / \mathrm{dm}^{3}$. In the same study Bertoni (2013) also informed the insecticidal activity of some pure compounds that are usually found in $O$. sanctum oil. For linalool, the fifth compound more abundant in our sample, it was estimated an $\mathrm{LC}_{50}=13.6 \mathrm{mg} / \mathrm{dm}^{3}$, which is close to those reported for essential oil $\left(10.4 \mathrm{mg} / \mathrm{dm}^{3}\right)$. On the other hand, the main compound (eugenol) only reaches the activity at $\mathrm{LC}_{50}=98.4 \mathrm{mg} / \mathrm{dm}^{3}$. Those findings confirm once against that the activity of one essential oil is not related to the activity of the main compound, but also by the synergistic effect of all chemical constituents (Bertoni, 2013; Pinto et al, 2015).

\section{Conclusions}

The essential oil of $O$. sanctum var. cubensis has a chemical composition capable of affecting all phases of the life cycle of $M$. domestica with no environmental side effects, extolling its potential as an effective insecticide against this species, which is the classic example of an insect that developed resistance to most known chemical insecticides.

\section{Conflict of interest}

The authors declare no conflict of interest.

\section{Acknowledgement}

This work was supported by the Instituto Oswaldo Cruz (IOC/FIOCRUZ); Conselho Nacional de Desenvolvimento Científico e Tecnológico (CNPq); Fundação Carlos Chagas Filho de Amparo à Pesquisa do Estado do Rio de Janeiro (FAPERJ); and Coordenação de Aperfeiçoamento de Pessoal de Nível Superior with Ministerio de Educación Superior de Cuba (CAPES-MES Cuba, number 130/11).

\section{References}

Abbott, WS. (1925). A method of computing the effectiveness of an insecticide. Journal of Economic Entomology, 18(2), 265-267.

Adenusi, A.A. and Adewoga, T.O.S. (2013). Studies on the potential and public health importance of non-biting synanthropic flies in the mechanical transmission of human enterohelminths. Trans R Soc Trop Med Hyg, 107(12), 812-818.

Aktar, M.W., Sengupta, D., Chowdhury, A. (2009). Impact of pesticides use in agriculture: their benefits and hazards. Interdisc Toxicol, 2(1), 1-12.

Bakkali, F., Averbeck, S., Averbeck, D. and Idaomar, M. (2008). Biological effects of essential oils-a review. Food Chem Toxicol, 46(2), 446-475.

Bertoni, A.O. (2013). Insecticida natural para el control de Musca doméstica en base a aceites esenciales y sus componentes. $\mathrm{PhD}$ thesis, Universidad Católica de Córdoba.

Bosly, A.H. (2013). Evaluation of insecticidal activities of Mentha piperita and Lavandula angustifolia essential oils against house fly, Musca domestica L. (Diptera: Muscidae). Journal of Entomology and Nematology., 5(4), 50-54.

Burt, S. (2004). Essential oils: Their antimicrobial properties and potential applications in foods: A review. Int. J. Food Microbiol., 94(3), 223-253.

Chapman, R.F. (2003). Contact chemoreception in feeding by phytophagous insects. Ann. Rev. Entomol., 48, 455-484.

Chavasse, D. C., Shier, R. P., Murphy, O. A, Huttly, S.R.A, Cousens, S.N., and Akhtar, T. (1999). Impact of fly control on childhood diarrhoea in Pakistan: community-randomised trial. THE LANCET, 353 (2), 22-25.

Chil-Núñez, I., Escalona-Arranz J.C, BerenguerRivas C. A., Mendonça, P.M, Mateo-Pérez, K., Dutok-Sánchez, C.M, Cortinhas, L.B., Silva, C.F and Queiroz M.M.C. (2017). Chemical Composition and Toxicity of Ocimum sanctum L. var. cubensis Essential Oil Up-Growing in the Eastern of Cuba. International Journal of Pharmacognosy and Phytochemical Research, 9(7), 1021-1028.

Chil-Núñez, I., Mendonça, P., Escalona-Arranz J.C, Cortinhas, L., Dutok-Sánchez, C.M and Queiroz, M.M.C. (2018). Insecticidal effects of Ocimum sanctum var. cubensis essential oil on the diseases vector Chrysomya putoria. Journal of Pharmacy \& Pharmacognosy Research, 6(3), 148-157. 
Collinet-Adler, S., Babji, S., Francis, M., Kattula, D., Premkumar, P.S., Sarkar, R., Mohan, V. R., Ward, H., Kang, G., Balraj, V. and Naumovab, E.N. (2015). Environmental Factors Associated with High Fly Densities and Diarrhea in Vellore, India. Applied and Environmental Microbiology, 81(17), 6053-6058.

David, G., Linda, J., Gahanc, S.W, Baxtera, Jian-Zhou Zhao, Anthony, M., Shelton, F., Goulde, B., Tabashnikd, E. (2007). The diversity of Bt resistance genes in species of Lepidoptera. Journal of Invertebrate Pathology, 95(3), 192197.

Edigenia, C.C., Arauä, J.O., Silveira, E.R., Lima, M.A.S., Neto, M.A, De Andrade, IL. and Lima, M.L.A. (2003). Insecticidal Activity and Chemical Composition of Volatile Oils from Hyptis martiusii Benth. J. Agric. Food Chem., 51(13), 3760-3762.

Environews Forum. (1999). Killer environment. Environ Health Perspect, 107(2), 62-63.

Georghiou, G.P. (1994). Principles of insecticide resistance management. Phytoprotection, 75(4), 51-59.

Graczyk, T. K, Knight, R., Gilman, R.H. and Cranfield, M.R. (2001). The role of non-biting flies in the epidemiology of human infectious diseases. Microbes Infect., 3(3), 231-5.

Greenberg, B. Flies and Disease. (1973). Vol. II: Biology and Disease Transmission. New Jersey: Princeton University Press; 447 pp.

Hadi, J.K., Salam, Y.B., Hoda, R.A., Lassi, Z.S. and Bhutta, Z.A. (2018). Fly control to prevent diarrhoea in children. Cochrane Database of Systematic Reviews. 12(12). Available from: https://www.researchgate.net/publication/32971 8894_Fly_control_to_prevent_dia

rrhoea_in_children [accessed May 22 2019].

Hantan, I. and Zaki, M.Z. (1998). Development of environment friendly insect repellents from the leaf oils of selected Malaysian plants. Rev. Biod. Environ. Cons, 1, 1-7.

Isman, M.B. (1997). Neem and other botanical insecticides: barriers to commercialization. Phytoparasitica Rehovot, 25(4), 339- 344.

Kasrati, A., Alaoui Jamali, C., Bekkouche, K., Spooner-Hart, R., Leach, D. and Abbad, A. (2015). Chemical characterization and insecticidal properties of essential oils from different wild populations of Mentha suaveolens sub sp. timija (Briq.) Harley from Morocco. Chem Biodivers. ,12(5),823-31.

Khan, H.A.A. (2017). Resistance to pyrethroid insecticides in house flies, Musca domestica L., (Diptera: Muscidae) collected from urban areas in Punjab. Pakistan Parasitology Research., 116 (12), 3381-3385.

Kumar, P., Mishra, S., Malik, A. and Satya, S. (2011). Repellent, larvicidal and pupicidal properties of essential oils and their formulations against the house fly. Musca domestica. Med. Vet. Entomol., 25(3), 302-310.

Kumar, P., Mishra, S., Malik, A. and Satya, S. (2013). Housefly (Musca domestica L.) control potential of Cymbopogon citratus Stapf. (Poales: Poaceae) essential oil and monoterpenes (citral and 1,8-cineole). Parasitol. Res, 112(1), 69-76. Lambert, R.J.W.; Skandamis, P.N.; Coote, P.; Nychas, G.J.E. (2001). A study of the minimum inhibitory concentration and mode of action of oregano essential oil, thymol and carvacrol. J. Appl. Microbiol., 91(3), 453-462.

Leblanc, L., Vargas, R.I., Mackey, B., Putoa, R., Piñero, J.C. (2011). Evaluation of cue-lure and methyl eugenol solid lure and insecticide dispensers for fruit fly (Diptera: Tephritidae) monitoring and control in Tahiti. Florida Entomol, 94 (3), 510-516.

Lindeberg, Y.L., Egedal, K., Hossain, Z., Phelps, M., Tulsiani, S., Farhana, I., Begum, A. and Jensen, M.P. K. (2018). Can Escherichia coli fly? The role of flies as transmitters of E. coli to food in an urban slum in Bangladesh. Tropical Medicine and International Health, 23 (1), 2-9. Miresmailli, S. and Isman, M.B. (2014). Botanical insecticides inspired by plantherbivore chemical interactions. Trends in Plant Science, 19 (1), 29-35.

Obeng-Ofori, D. and Reichmuth, Ch. (1997). Bioactivity of eugenol, a major component of essential oil of Ocimum suave (Wild.) against four species of stored-product Coleoptera. International Journal of Pest Management, 43(1), 89-94.

Pattanayak, P., Behera, P., Das, D. and Panda, S.K. (2010). Ocimum sanctum Linn. A reservoir plant for therapeutic applications: An overview. Pharmacogn Rev, 4(7), 95-105.

Pavela, R. (2008). Insecticidal properties of several essential oils on the house fly (Musca domestica). Phytother. Res., 22(2), 274-278.

Peter, R.J., Van den Bossche, P., Penzhorn, B.L., Sharp, B. (2005). Tick, fly, and mosquito control-Lessons from the past, solutions for the future. Vet Parasit, 132(3-4), 205-215.

Pinto, Z.T, Fernández-Sánchez, F., Santos, A.R., Amaral, A..C, Ferreira, J.L., Escalona-Arranz, J.C. and Queiroz, M.M.C. (2015). Effect of Cymbopogon citrates (Poaceae) oil and citral on post-embryonic time of blowflies. J. Entomol. Nematol, 7(6), 54-64.

Prakash, P. and Gupta, N. (2005). Therapeutic uses of Ocimum sanctum Linn (tulsi) with a note on eugenol and its pharmacological actions: A short review. Indian J Physiol Pharmacol, 49(2), 125-131.

Rashid, Md.H.Al., Banerje, A. and Jyoti, M.N. (2013). The queen of herb with potent 


\section{AMA更ONDA}

therapeutic constituent in various disease states: A reappraisal. International Journal of Phytomedicine, 5 (2), 125-130.

Ryan, M.F. and Byrne, O. (1998). Plant-Insect coevolution and inhibition of acetylcholinesterase. Journal of Chemical Ecology, 14, 1965-1975.

Sawabe, K., Hoshino, K., Isawa, H. et al. (2006). Detection and isolation of highly pathogenic H5N1 avian influenza a viruses from blow flies collected in the vicinity of an infected poultry farm in Kyoto, Japan. Am. J. Trop. Med. Hyg., 75(2), 327-332.

Sawabe, K., Hoshino, K., Isawa, H., et al. (2011). Blow Flies Were One of the Possible Candidates for Transmission of Highly Pathogenic H5N1 Avian Influenza Virus during the 2004 Outbreaks in Japan. Influenza Research and Treatment. ID

652652. doi:10.1155/2011/652652.

Schowalter, T.D. (2006). Insect ecology: an ecosystem approach. San Diego: Academic Press, 572p.

Shah, R.M., Shad SA, Abbas N. (2016). Methoxyfenozide resistance of the housefly, Musca domestica L. (Diptera: Muscidae): crossresistance patterns, stability and associated fitness costs. Pest Manag Sci, 73(1):254-261, DOI 10.1002/ps.4296.

Shono, T. and Scott, J.G. (2003). Spinosad resistance in the housefly, Musca domestica, is due to a recessive factor on autosome 1. Pest. Biochem. Physiol., 75(1-2), 1-7.

Sinthusiri, J. and Soonwera, M. (2013). Insecticides against the housefly Musca domestica L. Southeast Asian J. Trop. Med. Public Health, 44, 28-39.

Srinivasan, R., Jambulingam, P. and Gunasekaran, K. (2008). Boopathidoss PS Tolerance of housefly, Musca domestica (Diptera: Muscidae) to dichlorovos (76\% EC) an insecticide used for fly control in the tsunami-hit coastal villages of southern India. Acta Tropica, 105(2), 187-190.

Stroh, J., Wan, M.T., Isman, M.B and Moul, D.J. (1998). Evaluation of the acute toxicity to juvenile Pacific coho salmon and rainbow trout of some plant essential oils, a formulated product, and the carrier. Bull Environ Contam Toxicol, 60, 923-930.

Sukontason, K.L., Narongchal, P., Sripakdee, D., Boonchu, N., Chaiwong, T, Ngern-Klun, R., Piangjai, S. and Sukontason, K. (2005). First report of human myiasis caused by Chrysomya megacephala and Chrysomya rufifacies (Diptera: Calliphoridae) in Thailand, and its implication in forensic entomology. Journal of Medical Entomolgy, 42(4), 702-704.

Tawatsin, A., Asavadachanukorn, P., Thavara, U., Wongsinkongman, P., Bansidhi, J., Boonruad, T. et al. (2006). Repellency of essential oils extracted from plants in Thailand against four mosquito vectors (Diptera: Culicidae) and oviposition deterrent effects against Aedes aegypti (Diptera: Culicidae). Southeast Asian J Trop Med Public Health, 37(5), 915-931.

Themanma, C.A., Etusim, P.E., Kalu M.K., Adindu, R.U., Iruoha, A. (2013). Diptera: the order of great public health nuisance. Journal Env. Sci. Tox., 2(5), 135-143.

Vargas, R.I., Mau, R.F., Stark, J.D., Piñero, J.C., Leblanc, L. and Souder, S.K. (2010). Evaluation of methyl eugenol and cue-lure traps with solid lure and insecticide dispensers for fruit fly monitoring and male annihilation in the Hawaii Areawide Pest Management Program. Journal Econ Entomol, 103(2), 409-15.

Viegas-Junior, C. (2003). Terpenos com atividade inseticida: uma alternativa para $\mathrm{o}$ controle químico de insetos. Quim. Nova, 26(3), 390-400.

WHO. (1990). Public Health Impact of Pesticides Used in Agriculture. Geneva: World Health Organization, 88.

Wiegmann, B.M, Trautwein, M.D, Winkler, I.S, Barr, N.B, Kim J.W, Lambkin C, Bertone M.A. et. al, (2004). Natural indeed: Are natural insecticides safer and better than conventional insecticides? Illinois Pesticide Review, 17(3), 18 